Dzieje Najnowsze, Rocznik LI - 2019, 2

PL ISSN 0419-8824

\author{
Sławomir Moćkun \\ https://orcid.org/0000-0003-0010-5331 \\ Bruksela
}

\title{
Znaczenie munduru polskiego żołnierza w kultywowaniu tradycji i patriotyzmu wśród Polonii kanadyjskiej
}

\begin{abstract}
Abstrakt: Przez ponad sto lat głównym nośnikiem patriotyzmu wśród Polonii kanadyjskiej, obok polskiego kościoła, szkoły czy chóru, był mundur polskiego żołnierza. Czynnik ten niesłusznie był niedoceniany w badaniach nad Polonią kanadyjską. Kanada stanowiła ośrodek rekrutacyjny i treningowy dla Błękitnej Armii oraz Polskich Sił Zbrojnych na Zachodzie, odgrywających także olbrzymią rolę w promocji spraw polskich w Ameryce oraz wzmacniających uczucia patriotyczne Polonii. Po 1945 r. Kanada stała się bezpieczną przystanią dla tysięcy polskich żołnierzy niemogących powrócić do opanowanej przez komunistów Polski. Mundur i sztandar są nieodłącznym elementem, często najważniejszym, obchodzonych w Kanadzie polskich świąt narodowych i uroczystości patriotycznych.
\end{abstract}

Słowa kluczowe: Polonia w Kanadzie, Stowarzyszenie Polskich Kombatantów, Stowarzyszenie Weteranów Armii Polskiej (SWAP), święta narodowe.

Abstract: For over a hundred years, the main carrier of patriotism among Canadian Poles, next to the Polish Church, school or choir, was the uniform of a Polish soldier. This factor was wrongly underestimated in research on Canadian Polonia. Canada was a recruitment and training centre for the Blue Army and the Polish Armed Forces in the West, also playing an important role in promoting Polish affairs in America and strengthening the patriotic feelings of Polish Canadians. After 1945, Canada became a safe haven for thousands of Polish soldiers unable to return to communist-controlled Poland. The uniform and banner are an inseparable, often the most important element, of Polish national holidays and patriotic celebrations in Canada.

Key w or d s: Polonia in Canada, Polish Combatants' Association, Polish Army Veterans' Association in America (SWAP), national holidays. 
W sasiednich Stanach Zjednoczonych duma z bycia Polakiem i chwała polskiego munduru wiążą się z osobami Tadeusza Kościuszki i Kazimierza Pułaskiego. Polonia kanadyjska odwołuje się zaś do dorobku dwóch powstańców listopadowych, którzy wnieśli niemały wkład w polityczny, gospodarczy i wojskowy rozwój Kanady ${ }^{1}$. Jednym z nich był inż. sir Kazimierz Stanisław Gzowski, bardzo aktywnie zaangażowany $\mathrm{w}$ rozbudowę kanadyjskiej infrastruktury, a także w działalność społeczną i polityczną․ Drugi wybitny Polak to Aleksander Edward Kierzkowski, wywodzacy się z rodziny o dużych tradycjach wojskowych. Kierzkowski znalazł się w zaszczytnym gronie posłów kanadyjskiego parlamentu I kadencji ${ }^{3}$. Terytorium Kanady przyciagało także mniej znanych bojowników „o wolność waszą i naszą, jak Józef Smoliński czy Mikołaj Gustaw Szulc ${ }^{4}$ Powyższe przykłady, choć wybitne, były wciąż jednostkowe. Dopiero masowa emigracja zarobkowa z przełomu XIX i XX w. stworzyła rdzeń odrębnej polskiej grupy w Kanadzie, która na przestrzeni lat demonstrowała niezachwiane postawy patriotyczne.

Wybuch I wojny światowej zwrócił serca i wzrok osiadłych w Kanadzie Polaków nad Wisłę. Rząd w Ottawie wyraził zgodę na powstanie w położonym przy granicy ze Stanami Zjednoczonymi miasteczku Niagara-on-the-Lake obozu szkoleniowego The Tadeusz Kosciuszko Polish Army Training Camp. W ten sposób, na kanadyjskiej ziemi, wyszkolonych zostało ok. 23 tys. żołnierzy Błękitnej Armii. Zdecydowaną większość stanowili Polacy ze Stanów

\footnotetext{
${ }^{1}$ Weterani pochodzenia polskiego znaleźli się już wśród lojalistów, którzy po wojnie o niepodległość Stanów Zjednoczonych, pozostając wiernymi Zjednoczonemu Królestwu, przenieśli się na północ do kolonii brytyjskich. Na ziemie dzisiejszej Kanady trafili także Polacy walczący w armii napoleońskiej, którzy po wzięciu do niewoli wcieleni zostali w szeregi brytyjskiej armii i wysłani na kontynent północnoamerykański. A. Reczyńska, Polska diaspora w Kanadzie, w: Polska diaspora, red. A. Walaszek, Kraków 2001, s. 32-34; B. Makowski, Polska emigracja $w$ Kanadzie, Linz-Salzburg 1951, s. 14.

${ }^{2}$ Gzowski wniósł znaczacy wkład w budowę kanadyjskiej kolei, a także powstanie Kanału Wellandzkiego oraz mostu na rzece Niagara. Był także jednym z założycieli Komisji Parków Niagary (i pierwszym jej komisarzem), Kanadyjskiego Stowarzyszenia Inżynierów Lądowych oraz administratorem prowincji Ontario. Jako przyjaciel premiera Johna Macdonalda w latach 1896-1897 pełnił nieoficjalnie funkcję gubernatora porucznika prowincji Ontario. W 1890 r. otrzymał od królowej Wiktorii tytuł szlachecki. Dictionary of Canadian Biography, t. XII, Toronto 2000; W. Turek, Sir Casimir S. Gzowski, Toronto 1957.

${ }^{3}$ Kierzkowski osiadł w pobliżu miejscowości Saint-Hyacinthe (nazwanej imieniem popularnego także we Francji polskiego św. Jacka Odrowąża). Ożenił się z córką bogatego arystokraty Pierre'a-Dominique'a Debartzcha, potomka jednego z pionierów polskiej emigracji do Kanady. Został członkiem władz Agricultural Society Dolnej Kanady, a także sędzią pokoju. Kontynuował zamiłowanie wojskowe - został adiutantem kwatermistrza generalnego V Okręgu Wojskowego Wschodniej Kanady oraz oficerem batalionu miejscowej milicji. B. Makowski, op. cit., s. 22-23; Dictionary of Canadian Biography..., t. IX, Toronto 2000; L.J. Kos-Rabcewicz-Zubkowski, Alexandre-Edouard Kierzkowski, Patriote Polonais, réfugié au Canada (1816-1870), „Le Bulletin des Recherches Historiques” 1954, t. LX, nr 4, s. 175-180.

${ }^{4}$ Zob. W. Makowski, The Polish People in Canada. A Visual History, Montreal 1987, s. 25-40.
} 
Zjednoczonych, a pod dowództwo gen. Józefa Hallera trafiło niewiele ponad 200 żołnierzy z Polonii kanadyjskiej. Werbunek wspomagała kampania rekrutacyjna, rozprzestrzeniająca się daleko poza centra rekrutacyjne w Winnipeg (Manitoba), Toronto (Ontario) i St. John's (Quebec). Naturalną strategię rekrutacji stanowiło rozbudzanie na wszelkie sposoby uczuć patriotycznych. Współdziałanie w czasie wojny było „najpiękniejszym przykładem wierności zasad i przywiązania do Macierzy" - wspominał gen. Haller, który także w późniejszych latach odwiedzał miejsce byłego obozu szkoleniowego. Niestety, nie dało się podczas tych pobytów nie zauważyć animozji, które kształtowały podziały polityczne nad Wisła ${ }^{5}$.

Typowo pionierskie warunki obozowania oraz sroga zima sprawiły, iż kilkudziesięciu Polaków nie doczekawszy wyruszenia na front, zmarło w obozach. Miejsce ich pochówku stało się symbolem współpracy polsko-kanadyjsko-amerykańskiej. W obozie wzniesiono także pomnik ku czci poległych Kanadyjczyków, udekorowany przez gen. Józefa Hallera Krzyżem Walecznych. Cmentarz w Niagara-on-the Lake do dzisiaj jest miejscem pielgrzymek Polonii amerykańskiej i kanadyjskiej. Stowarzyszenie Weteranów Armii Polskiej w Ameryce (SWAP), aktywne także w Kanadzie, nie tylko kultywowało pamięć o północnoamerykańskich ochotnikach Błękitnej Armii, ale również włączało się w patriotyczne inicjatywy i zaangażowało się w opiekę nad „narodowa polska pamiątka w Kanadzie" ${ }^{\circ}$.

Duża część imigrantów przybyłych do Kanady po 1918 r. miała za sobą służbę w polskim wojsku. Część z nich skupiła się w powstałym w $1930 \mathrm{r}$. Zwiąku Weteranów Polskich im. Marszałka J. Piłsudskiego w Montrealu. „Równocześnie ślubujemy, że ani odległość, ani długie lata rozłąki nie zdołaja wyrwać z naszych serc żołnierskich tej gorącej miłości, jaką żywią dla Ciebie i Ojczyzny byli Twoi żołnierze, że pozostaniemy wierni zawsze naszym zasadom i tradycjom żołnierskim, że godnie będziemy reprezentować imię Polaka na obczyźnie"7 - czytamy w przyjętej trzy lata później deklaracji nadającej organizacji imię Marszałka Józefa Piłsudskiego. Montrealskie stowarzyszenie, podobnie jak duża część weteranów, przystapiło także do gwarantującego wsparcie państwa Legionu Kanadyjskiego. Polska sekcja działająca w ramach

5 J. Haller, W marszu do zwycięstwa, Londyn, „Odsiecz. Polska Walcząca w Ameryce”, 3 VIII 1941, t. I, nr 1-2, s. 3.

${ }^{6}$ Archiwum Akt Nowych (dalej: AAN), 503/1412, Raport KG RP w Montrealu do MSZ w Warszawie w celu uregulowania opieki nad cmentarzem w Niagara-on-the-Lake, Montreal 7 X 1924, k. 2-5; J. Roskosz, Polacy w Armji Kanadyjskiej w czasie wielkiej wojny światowej, „Narodowiec”, 26 VII 1936; J. Plewko, Duszpasterstwo Polonii w procesie jej integracji ze społeczeństwem kanadyjskim (1875-1988), Lublin 1995, s. 319-322; B. Makowski, op. cit., s. $58-59$.

${ }^{7}$ Z kolei w Oshawa powstała kilka lat później bliźniacza organizacja, która przyjęła imię gen. W. Sikorskiego. Zob. Z. Małecki, Księga jubileuszowa 65-lecia Zwiqzku Weteranów Polskich im. Marsz. Józefa Pitsudskiego w Montrealu, 1930-1995, Montreal 1995. 
Canadian Legion wielokrotnie występowała w obronie dobrego imienia państwa polskiego ${ }^{8}$. Kombatanci stanowili więc może niezbyt liczny, ale istotny trzon patriotycznej Polonii. W Windsor SWAP liczyło 25 osób, by po przyjęciu zdemobilizowanych żołnierzy Polskich Sił Zbrojnych (PSZ) na Zachodzie w latach pięćdziesiątych powiększyć się do 200 członków ${ }^{9}$. Z kolei placówka z Toronto współpracowała z Federacją Polskich Związków Obrońców Ojczyzny, która ufundowała sztandar. Wielu liderów polonijnych miało za soba kombatancką przeszłość, tak jak zasłużony dla rozwoju oświaty Jan Sikora, żołnierz Legionów Polskich ${ }^{10}$. Na mniejszą skalę niż w sąsiednich Stanach Zjednoczonych rozwijały się ruchy sokoli oraz harcerski współtworzony także przez osoby związane z polskim mundurem ${ }^{11}$. Polonia przechodziła wówczas powolny proces konsolidacji, a główne organizacje, z uwagi na geograficzne ograniczenia i różne programy, często rywalizowały ${ }^{12}$.

Do 1939 r. większość obchodów patriotycznych miała charakter lokalny, odbywając się głównie w kościołach, domach polskich i wynajętych salach, niejednokrotnie zbyt małych, by pomieścić kilkusetosobowe rzesze Polonii. Obchodzone święta państwowe, głównie w postaci uroczystego nabożeństwa oraz akademii, nie różniły się od podobnych uroczystości organizowanych przez większość polonijnych skupisk. 1 XII $1929 \mathrm{r}$ w Montrealu odbyły się obchody pamięci „wszystkich naszych walk o wolność w epoce porozbiorowej” ${ }^{13}$. Dopiero w 1933 r. w Winnipeg po raz pierwszy zorganizowano obchody wymarszu Legionów połączone z rocznicą Cudu nad Wisła. Inicjatywa SWAP nie została wsparta przez „Gazetę Katolicką, która odwołując się do argumentacji endecji, zdystansowała się wówczas od legionowych rocznic. Podobnie było ze Świętem Morza ${ }^{14}$. Weterani zaangażowali się w organizację 250. rocznicy bitwy pod Wiedniem. 15. rocznica odzyskania niepodległości w Winnipeg, zorganizowana przez polski oddział Legionu Kanadyjskiego, poświęcona była polsko-kanadyjskiemu braterstwu broni. W nowo powstałym Związku

8 16-lecie działalności polskiej placówki Legjonu Kanadyjskiego, „Polacy Zagranica” 1935, nr $1-2$, s. 26.

9 A. Rajski, 100 lat Polonii w Windsor 1908-2008, Windsor 2008, s. 72.

${ }^{10}$ AAN, 322/1324, Życiorys Jana Sikory, [b.d.], k. 5.

${ }^{11}$ Historia Polskiego Towarzystwa Gimnastycznego Sokót w Kanadzie, „Przegląd Sokoli” 2006, nr 22, s. 2-3; AAN, 340/186, Sprawozdanie z uroczystości wręczenia sztandaru ufundowanego przez gen. Romana Góreckiego, Ottawa, 21 III 1938, k. 4-5.

12 Najważniejsze organizacje w tym czasie stanowiły związane z oblatami Stowarzyszenie Polaków w Kanadzie (wydawca „Gazety Katolickiej”), Związek Polaków w Kanadzie o charakterze socjalistycznym i świeckim (organ prasowy „Związkowiec”), wspierane przez polskich konsulów i Światowy Związek Polaków z Zagranicy jako centralna organizacja polonijna, Zjednoczenie Zrzeszeń Polskich w Kanadzie (wydajace pismo „Czas”) oraz komunistyczne Polskie Towarzystwo Robotniczo-Farmerskie wydające „Głos Pracy”.

${ }^{13}$ AAN, 322/8583, Sprawozdanie KG RP w Montrealu z akademii poświęconej pamięci walk o niepodległość, Montreal, 6 XII 1929, k. 2.

14 AAN, 503/1189, Prasa polska wobec uroczystości sierpniowych, Winnipeg, 13 IX 1933, k. $46-50$. 
Obrońców Ojczyzny otwarto Czytelnię im. Marszałka Piłsudskiego. Podobne obchody, jak również rocznicę wybuchu powstania listopadowego zorganizowało Towarzystwo Gimnastyczne „Sokół”15. Kilka miesięcy później, a także w kolejnych latach dzięki staraniom konsulatu imieniny Marszałka, świętowane wraz z rocznica powstania kościuszkowskiego, połączyły już kilka organizacji, oddając przy tym coraz silniejszy trend konsolidacyjny ${ }^{16}$. Swego rodzaju świętem dla polonijnych kombatantów, ale i ich kanadyjskich kolegów była wizyta w Montrealu w październiku 1931 r. gen. Gustawa Orlicza-Dreszera ${ }^{17}$.

Pierwsza w historii polsko-kanadyjska uroczystość na dużą skalę, z udziałem najważniejszych polityków, wiązała się z 100. rocznicą bitwy pod Windmill, w której główną rolę odgrywał uważany za Polaka Mikołaj Gustaw Szulc (Nils Gustaw Schoultz-Szołtewski), a uczestniczyli także inni Polacy - m.in. Ernest Berent i Jan Okoński. W zorganizowane latem 1938 r. obchody zaangażowało się Ministerstwo Spraw Zagranicznych w Warszawie. O wspaniałomyślności i rycerskich cechach Polaka pisała prasa w Ottawie i Toronto. W specjalnej akademii, transmitowanej na cała Kanadę przez radio, uczestniczyło 2 tys. osób, w tym kompanie kanadyjskiego i amerykańskiego wojska oraz harcerze. Uroczystości, przy licznym udziale Polonii (ok. 400 osób), w tym orkiestry, kombatantów w mundurach oraz z pocztami sztandarowymi, duchowieństwa, miały bardzo podniosły przebieg, chociaż z uwagi na ulewny deszcz odwołano uroczysta paradę. Podczas obchodów wielokrotnie odgrywano hymny polski, brytyjski i amerykański. Doskonałe przemówienie, m.in. o Polsce i Polonii, wygłosił reprezentujący kanadyjski rząd senator George Graham. „[...] marzyciel i rycerz śniący o niepodległości Polski, szedł na ziemię kanadyjską do boju, chcąc na nowo wzbudzić tradycje Kościuszki i Pułaskiego i postawić znów przed oczy świata sprawę Polski"18 - mówił do zgromadzonej Polonii konsul generalny Jan Pawlica. W ostatniej części - odsłonięciu pamiątkowej tablicy i złożeniu kwiatów - udział wzią premier William Lyon Mackenzie King, który docenił zaangażowanie strony polskiej w ważnych dla Kanadyjczyków uroczystościach. Szczególnie dla niego cennych, gdyż podczas bitwy zginęli dwaj jego przodkowie, walczący po przeciwnych stronach ${ }^{19}$.

${ }^{15}$ Ibidem, Sprawozdania z obchodów rocznicy odzyskania niepodległości, Winnipeg, 16 XI 1933, k. 51-55.

${ }^{16}$ AAN, 503/1210, Sprawozdanie KG RP w Winnipeg do MSZ w Warszawie z obchodów imienin Marszałka J. Piłsudskiego, Winnipeg, 19 III 1935, k. 16-17.

${ }_{17}$ AAN, 322/4439, Sprawozdanie KG RP w Montrealu do MSZ w Warszawie z wizyty gen. G. Orlicz-Dreszera, Montreal, 10 XI 1931, k. 8.

18 AAN, 322/1078, Przemówienie Konsula Generalnego Jana Pawlicy, [b.d.], k. 62.

${ }_{19}$ Gustaw Szulc, dowódca grupy podczas potyczki pod Windmill Point (11-16 X 1838), największego starcia tej wyprawy, mimo obrony Johna Macdonalda (późniejszego premiera) został skazany na karę śmierci. Z czasem wyprawa uzyskała pozytywną ocenę Kanadyjczyków i tamtejszej Polonii. B. Makowski, op. cit., s. 18; AAN, 322/1078, Sprawozdanie J. Pawlicy do MSZ w Warszawie z obchodów 100-nej rocznicy bitwy pod Windmill, Ottawa, 7 VII 1938, k. 55-63; ibidem, Życiorys Gustawa von Schultza, k. 103-127. 
W Warszawie postanowiono także wykorzystać przypadająca w tym samym roku 40. rocznicę śmierci Gzowskiego, co miało służyć dalszemu ożywieniu ducha polskiego wychodźstwa, zbliżenia polsko-kanadyjskiego oraz poprawy wizerunku Polonii ${ }^{20}$. Organizacja uroczystości nabrała także wymiaru zjednoczeniowego dla Polonii w Toronto, a do komitetu honorowego zaproszono wpływowych kanadyjskich polityków i wojskowych ${ }^{21}$.

Nastroje patriotyczne wzrosły wraz z zaognieniem sytuacji w Europie i wybuchem wojny. Nawet w najmniejszych polonijnych skupiskach organizowano specjalne uroczystości z okazji świąt i rocznic historycznych. Dochód z nich przeznaczano na Fundusz Obrony Narodowej (FON) czy pomoc polskim jeńcom. Do września 1939 r. bardzo aktywny w organizowaniu patriotycznych inicjatyw Związek Weteranów Polskich w Montrealu na FON zebrał ponad 600 dolarów $^{22}$. Z uwagi na swoją symbolikę w starciu z nazistowskimi Niemcami szczególne miejsce zajmowało pierwsze polskiego święto państwowe - rocznica bitwy pod Grunwaldem. Kolejną ważną uroczystością było 150-lecie uchwalenia Konstytucji 3 maja. „Tak, jak przed 80-ciu laty nasi Bracia rwali kajdany niewoli - i dzisiaj cały Naród Polski walczy o wyzwolenie" 23 - zachęcano z kolei do udziału w obchodach 80. rocznicy wybuchu powstania styczniowego.

Szczególnie w tym okresie największy wpływ na obudzenie uczuć patriotycznych wśród w dużym stopniu zasymilowanej młodzieży miał mundur polskiego żołnierza. Polski rząd uznał, iż opinia amerykańska, a także w o wiele mniejszym stopniu kanadyjska, odegra decydująca rolę przy zawieraniu pokoju. Konieczne więc stało się jak najszersze i stałe wpajanie wiedzy o wkładzie Polski w wojnę. Umożliwiła to decyzja o powołaniu w Kanadzie, wzorem wcześniejszych lat, polskiego wojska. Utworzone w Windsor (ośrodek rekrutacyjny) i Owen Sound (obóz szkoleniowy) polskie formacje odgrywać miały bardzo istotną rolę propagandowa, ważniejszą nawet niż ich potencjał wojskowy.

„Mieszaja się mundury oficerskie i battle dress'y z mundurami Weteranów i cywilnymi strojami” ${ }^{24}$ - czytamy w relacji z powitania gen. Bronisława Ducha w Montrealu 19 VII 1941 r. Z chwilą zainstalowania polskich oficerów

${ }^{20} \mathrm{O}$ skali zaniedbań w tym względzie świadczy fakt, iż w okresie wzmożenia prosowieckich nastrojów podczas wojny Gzowskiego często przedstawiano jako... wybitnego Rosjanina.

${ }^{21}$ AAN, 503/119, Raport W. Podoskiego do MSZ na temat akcji informacyjno-propagandowej Placówki, Ottawa, 20 II 1940, k. 121; AAN, 322/1078, Korespondencja KG RP w Ottawie z MSZ w Warszawie na temat organizacji obchodów 40-tej rocznicy śmierci K. Gzowskiego, Ottawa-Warszawa, 28 II 1938, k. 13.

22 AAN, 322/11294, Wniosek Konsulatu RP w Montrealu do MSZ w Warszawie o podarowanie popiersia J. Piłsudskiego, Montreal, 4 VIII 1939, k. 20.

${ }^{23}$ S. Moćkun, Kultywowanie tradycji polskich $w$ Kanadzie przez Polonię i emigrację wojenna w latach 1939-1945, w: Paryż - Londyn - Monachium - Nowy Jork. Powrześniowa emigracja niepodległościowa na mapie kultury nie tylko polskiej, t. II, red. V. Wejs-Milewska, E. Rogalewska, Białystok 2016, s. 94-98.

${ }^{24}$ Od brzegów Atlantyku do Windsoru, „Odsiecz. Polska Walcząca w Ameryce”, 3 VIII 1941, t. I, nr $1-2$, s. 11. 
w Windsor do dowództwa zaczęły napływać zaproszenia na różnego rodzaju uroczystości z terenu Kanady i USA. Dawało to bezpośrednia możliwość promowania polskiego munduru, prowadzenia propagandy informacyjnej, a także wzmacniało uczucia patriotyczne. Podjęta aktywność w dużym stopniu nadrobiła zaniedbania w polskiej propagandzie w Ameryce Północnej. Polonia z całej Ameryki organizowała wycieczki do polskiego żołnierza, urządzając występy chórów, teatrów czy zespołów ludowych. Przedstawiciele Polskiej Misji Wojskowej byli zapraszani jako honorowi goście na niemal wszystkie w Kanadzie i Stanach Zjednoczonych polonijne uroczystości o charakterze patriotycznym, ale także kulturalnym czy rozrywkowym. Delegacje polskich żołnierzy uczestniczyły w uroczystościach w Niagara-on-the-Lake. W Zaduszki na cmentarzu wartę pełnili rekruci. W Windsor i Owen Sound organizowano również obchody polskich świąt państwowych. Udział w delegacjach dawał także wymierne rezultaty, zachęcając Polonię do większej ofiarności na rzecz pomocy walczącej Polsce i będacym w katastrofalnej sytuacji rodakom ${ }^{25}$.

1 IX 1941 r. nastapiło symboliczne przekazanie kluczy do miasta Owen Sound gen. Duchowi. Mieszkańcy miasteczka, dzięki przybyłemu z Toronto zespołowi Związku Polaków w Kanadzie, mieli okazję do zapoznania się z polska kultura - strojami ludowymi, pieśniami i tańcami ${ }^{26}$. Od września 1941 r. w ciagu roku odbyło się 36 podobnych imprez - wieczornic żołnierskich, przedstawień teatralnych (m.in. komedia Wojna z żonami odegrana w listopadzie $1941 \mathrm{w}$ Windsor przez artystów polskich z USA) czy koncertów z okazji rocznic. 29 listopada w Toronto oficerowie i żołnierze z Owen Sound zorganizowali wielki koncert w rocznice wybuchu powstania listopadowego. Liczaca ponad 2500 miejsc salę wypełniła miejscowa Polonia, ale także władze miasta, rektor uczelni czy kanadyjscy wojskowi. Szczególną okazję do manifestacji łączności Wojska Polskiego z Polonią stanowiły święta Bożego Narodzenia ${ }^{27}$.

Bardzo wzruszajace były podniosłe pożegnania ochotników do polskiego (lub kanadyjskiego) wojska, mające charakter lokalnych uroczystości. Obok rodziny, sąsiadów i przyjaciół często uczestniczyli w nich polscy żołnierze i konsulowie. Wielu rekrutów było synami weteranów z czasów I wojny światowej. „Jednego mam syna, ale go składam u stóp naszej umęczonej Polski, i on musi być żołnierzem, nie dziś, to jutro. Ja miałam lat 13, gdy byłam posyłana w najniebezpieczniejsze miejsca w 1920 roku"28 - wspominała

${ }^{25}$ O budowie Wojska Polskiego w Kanadzie zob. F. Kmietowicz, Polskie Sity Zbrojne w Kanadzie podczas drugiej wojny światowej, Windsor 1984; S. Moćkun, Bezpieczna przystań. Kanada i Polonia kanadyjska wobec Polski i Polaków w latach 1939-1945, Warszawa 2015; J. Smoliński, Polonia obu Ameryk w wojskowo-mobilizacyjnych planach Rzqdu RP na uchodźstwie (1939-1945), Warszawa 1998.

${ }^{26}$ Klucze Owen Sound w rękach polskich, „Odsiecz. Polska Walcząca w Ameryce”, 7 IX 1941, t. I, nr 6, s. 8.

${ }^{27}$ Nasza Kronika, „Odsiecz. Polska Walcząca w Ameryce”, 12 IV 1942, t. II, nr 16 (38), s. 5.

${ }^{28}$ Serce kobiety wskazuje droge, „Odsiecz. Polska Walcząca w Ameryce”, 21 IX 1941, t. I, nr 8, s. 1. 
Konstancja Godlewska z Montrealu w liście do gen. Ducha. Równie uroczysty charakter miały chrzciny, podczas których często ojcami chrzestnymi zostawali oficerowie Wojska Polskiego, a zebrane pieniądze przeznaczano na cele związane z polskim wojskiem lub akcje charytatywne na rzecz polskich jeńców czy ludności cywilnej.

Mundur polskiego żołnierza udowadniał, że Polska istnieje, a rząd polski działa. Armia jednoczyła Polonię Nowego Świata, pokazywała, że wolna, zasobna i liczna Polonia może stanowić istotne wsparcie dla walczacych na Starym Kontynencie rodaków. Podziw budziły historie rekrutów, którzy z okupowanej Polski, przez Syberię i Japonię, przemierzyli nieraz pół świata, by przystapić do organizowanej w prowincji Ontario polskiej armii. Historie ochotników z Europy czy obu Ameryk, ich poświęcenie, by włożyć mundur z przyszytym na ramieniu skrawkiem purpury z napisem „Poland”, dawały powszechne świadectwo, iż Polska wciąż walczy. „Żołnierz Polski przestał być dla Polaków amerykańskich tylko symbolem. Stał się żywym, z ich krwi i kości, ucieleśnieniem dumy z przynależności do wielkiego Narodu" ${ }^{29}$ czytamy w „Odsieczy”.

Oficerowie z Polskiej Misji Wojskowej sami wychodzili z licznymi inicjatywami promocji Polski, naturalnie głównie poprzez prezentację pozytywnego wizerunku polskiej armii. Taki cel miały m.in. organizacja wystawy fotograficznej polskiego wojska i rozpowszechnianie wydawnictw. Szczególne zainteresowanie budziła dwudziestopięciominutowa kolorowa produkcja filmowa Wojsko Polskie w Kanadzie. Sukcesem w Stanach Zjednoczonych okazał się także film Polska $i$ Jej żotnierze na wszystkich frontach. Niestety, była to produkcja polskojęzyczna, nie mogła więc dotrzeć do anglosaskiego odbiorcy. W samym tylko kwietniu i maju 1942 r. w 26 kinach obejrzało ja 19 tys. widzów. Rozpowszechniano także filmy krótkometrażowe o życiu w polskich koszarach, wyświetlane w salach kinowych niemal całej Kanady ${ }^{30}$.

Bardzo istotne znaczenie miała wydawana przez polskie wojsko „Odsiecz. Polska Walczaca w Ameryce", sprzedawana w 79 punktach w Stanach, 10 w Kanadzie i 1 w Wielkiej Brytanii. Niektóre spośród 38 numerów osiagały nakład ok. 22 tys. egzemplarzy, przy czym połowa kolportowana była bezpłatnie. W Owen Sound i Windsor zorganizowano wojskowy chór i orkiestrę. Ogółem od lipca 1941 r. do kwietnia 1942 r. wyprodukowano 144 audycje, a amerykańskie i kanadyjskie radiostacje nadały 36 przemówień. Wydano 197400 egzemplarzy broszur i różnego rodzaju publikacji, zorganizowano 107 projekcji filmowych oraz 36 imprez informacyjno-propagandowych.

${ }_{29}^{2}$ Po stowach musi nastapić czyn, „Odsiecz. Polska Walcząca w Ameryce”, 24 VIII 1941, t. I, nr 4, s. 1.

${ }^{30}$ Instytut Polski i Muzeum im. gen. Sikorskiego w Londynie (dalej: IPMS), A.X.1/4, Załącznik „Imprezy” do Sprawozdania kulturalno-oświatowych i propagandowych Polskiej Misji Wojskowej w Kanadzie, [b.m., b.d.], k. nlb. 
Redakcja „Odsieczy” opublikowała również śpiewniki czy komiks Przygody Walentego Pompki z rysunkami Mariana Walentynowicza ${ }^{31}$.

Zewnętrzna aktywność wojska szła w parze $\mathrm{z}$ „tęsknotą" Polonii północnoamerykańskiej za widokiem polskiego munduru. Potwierdzały to bardzo liczne zaproszenia na obchody i akademie publiczne, przedstawienia teatralne, koncerty i wieczory literackie, zabawy taneczne, zawody sportowe, a także uroczystości prywatne. Udział przedstawicieli polskiego wojska w polonijnych uroczystościach uznawany był za zaszczyt, często stanowił główna atrakcję wydarzenia, zwiększając tym samym wyniki przeprowadzanych na cele polskie zbiórek. Doszło nawet do takiej sytuacji (15 VIII 1942 w Saint Catherine), iż z powodu odwołania przyjazdu wojskowego delegata nie odbyła się impreza. Liczba zaproszeń była tak duża, iż na mniej istotne wydarzenia zamiast delegatów wysyłano telegraficzne życzenia. Od przyjazdu polskich oficerów do Kanady do końca listopada 1942 r. 62 delegacje wojskowe, nie wliczając wyjazdów samego szefa Misji, brały udział w wydarzeniach w USA i Kanadzie. Szef Polskiej Misji Wojskowej promując rekrutację, przemierzył niemal cała Kanadę, odwiedzając większość głównych skupisk Polonii ${ }^{32}$. Na początku 1942 r. gen. Duch odbył kolejny długi objazd po skupiskach Polonii amerykańskiej. W „Odsieczy” informowano, że wyjazdy te nie mają na celu „bezpośredniej akcji informacyjnej, czy zbiórkowej”, a wizyty Polonię „jednocza, wzmacniaja, budzą uświadomienie narodowe, zacieraja niekiedy wśród młodzieży wychowanie w duchu amerykańskim" ${ }^{33}$. Liczne były także wycieczki z terenu Kanady i USA do koszar w Windsor i Owen Sound, gdzie nierzadko organizowano dla gości specjalne wieczory żołnierskie.

Polska Misja Wojskowa przyczyniała się do pogłębienia współpracy ze Stanami Zjednoczonymi nie tylko w ramach licznych delegacji, konferencji i sympozjów u południowego sasiada Kanady, ale także organizując polsko-amerykańskie inicjatywy na terenie Windsor i Owen Sound, jak amerykańskie Święto Flagi (14 czerwca). Wojskowi przebywajacy w Kanadzie podczas urlopów chętnie korzystali z okazji do zwiedzenia Stanów Zjednoczonych. Grupa polskich żołnierzy uczestniczyła m.in. w paradzie z okazji obchodzonego w USA „Dnia Pułaskiego”. „Ojcom na chwałę, braciom na wytrwanie, potomności na wzór" ${ }^{34}$ - mówił gen. Duch 7 IX 1941 r. podczas akademii w Detroit ku czci

${ }^{31}$ S. Moćkun, Bezpieczna przystań..., s. 373-374.

${ }^{32}$ IPMS, A.X.1/4, Załącznik nr 3 „Delegacje członków Polskiej Misji Wojskowej do USA i Kanady za czas od czerwca do listopada 1942” do sprawozdania „prac kulturalno-oświatowych i propagandowych Polskiej Misji Wojskowej w Kanadzie, 1 IX 1941 do 30 IV 1942, [b.m., b.d.], k. nlb.

${ }^{33}$ Gen. Duch wśród Polonii U.S., „Odsiecz. Polska Walcząca w Ameryce”, 22 III 1942, t. II, nr 12 (34).

${ }^{34}$ Hołd pamięci $i$ wierności ideałom Ignacego Paderewskiego, „Odsiecz. Polska Walcząca w Ameryce”, 14 IX 1941, t. I, nr 7, s. 8; AAN, 490/2857, Raport Konsualtu RP w Pittsburgu do Ambasady RP w Waszyngtonie z uroczystości żałobnych ku czci śp. Prez. 
Ignacego J. Paderewskiego, nawiąując do słów wypisanych na krakowskim pomniku Grunwaldzkim ufundowanym przez wielkiego kompozytora, podkreślając znaczenie świąt państwowych i rocznic historycznych. Z kolei płk Janusz Iliński reprezentował Polską Misję Wojskową w Kanadzie na pogrzebie gen. Bolesława Wieniawa-Długoszowskiego w Nowym Jorku w lipcu 1942 r..$^{35}$

Delegowani przez dowództwo oficerowie i szeregowi znający w odpowiednim stopniu język angielski wygłosili w szeregu miejscowości, na zaproszenie wielu kanadyjskich klubów i organizacji, 16 odczytów na temat udziału Polski w wojnie. Aktywność ta miała dla odbiorców szczególne znaczenie, gdyż przemawiajacy żołnierze o postawie Polski świadczyli własnymi przeżyciami bojowymi. Przedstawiciele polskiego wojska wzięli m.in. udział w „Święcie Morza" i Dniu Przyjaźni Polsko-Czechosłowackiej, organizowanych przez Zwiazek Narodowy Polski pod koniec czerwca 1942 r. w Toronto. SWAP 6 IX 1942 r. urządziło w Hamilton obchody 3. rocznicy napaści na Polskę, połączone ze Świętem Żołnierza ${ }^{36}$.

Szczególny charakter miały uroczystości z okazji Święta Żołnierza zorganizowane w Windsor. Trzydniowe obchody były „potężna manifestacja narodowej jedności i woli”. Rozpoczęły się w piątek od audycji radiowej z odtworzonym przemówieniem Naczelnego Wodza oraz udziału oficerów wszystkich rodzajów broni z gen. Duchem na czele. Do Windsor przybyli przedstawiciele organizacji polonijnych ze Stanów Zjednoczonych i Kanady, którzy złożyli uroczyste ślubowanie podkreślające przywiązanie do Polski i zadeklarowali wszechstronna pomoc. „Zwarta i solidarna, bez względu na partie i przekonania, cała prasa polska stać będzie u boku Polski Walczącej i Jej widomego znaku na ziemi amerykańskiej - potężnej jednostki Armii Polskiej, przez nas tu zbudowanej"37 - czytamy z kolei w rezolucji przyjętej przez przedstawicieli prasy polskiej. Podkreślano scalający wszystkich Polaków charakter tego święta. „Aczkolwiek dzielą nas przekonania polityczne, społeczne i religijne, to jednak jednoczy nas wspólna sprawa Polski” - mówił przedstawiciel Polskiego Narodowego Kościoła Katolickiego Józef Mikuta ze Scranton w Pensylwanii. Wzruszającym momentem była msza św. polowa wraz z Apelem Poległych, z udziałem tysięcy osób, na miejscowym stadionie ${ }^{38}$.

I.J. Paderewskiego organizowanych przez Centralny Komitet Obywatelski, Pittsburgh, 16 IX 1941, k. 197.

${ }^{35}$ AAN, 490/3113, Pismo Ambasady RP w Waszyngtonie do Departamentu Stanu w sprawie wizy dla płk. J. Ilińskiego, Waszyngton, 2 VI 1942, k. 423.

${ }^{36}$ IPMS, A.X.1/4, Załącznik nr 3 „Delegacje członków Polskiej Misji Wojskowej do USA i Kanady za czas od czerwca do listopada 1942” do sprawozdania „prac kulturalno-oświatowych i propagandowych Polskiej Misji Wojskowej w Kanadzie, 1 IX 1941 do 30 IV 1942, [b.m., b.d.], k. nlb.

${ }^{37}$ Święto Żotnierza Polskiego i Polonii Amerykańskiej, „Odsiecz. Polska Walcząca w Ameryce”, 24 VIII 1941, t. I, nr 4, s. 7.

${ }^{38}$ Ibidem. 
Nieco inaczej przebiegały uroczystości w następnym roku, kiedy to odstapiono już od ambitnych planów budowy na kanadyjskiej ziemi licznych formacji Wojska Polskiego. Decyzją Londynu obchody Święta Żołnierza zorganizowane były wewnatrz Misji, a akcja propagandowa z tej okazji ograniczyła się w zasadzie do prasy i radia. Szczególne znaczenie przypadło więc polskim organizacjom w Kanadzie i Stanach Zjednoczonych, którym o zbliżającym się Święcie Żołnierza Polskiego i jego znaczeniu w specjalnym liście przypomniał szef Polskiej Misji Wojskowej w Kanadzie płk Stefan Sznuk $^{39}$. „Związkowiec” z okazji zbliżającego się święta przygotował specjalne życzenia, szeroko informując czytelników o programie uroczystości w Toronto, zorganizowanych przez Zjednoczenie Zrzeszeń Polskich, Związek Narodowy Polski i SWAP ${ }^{40}$. Specjalne przemówienie wygłosił przedstawiciel Polskich Sił Powietrznych, oświadczając, że „on jako Lotnik jeden ma cel przed sobą: bić wroga i wyzwolić Ojczyznę naszą z kajdan niewoli”. Krótkie wystapienie żołnierza nagrodzone zostało długotrwałymi oklaskami oraz spontanicznym trzykrotnym okrzykiem: „Niech żyją Polskie Siły Zbrojne”. Kółko teatralne odegrało jednoaktowe przedstawienie Żotnierz. Nie zabrakło również poezji dziecięcej. W lasku Summerville odbył się piknik ${ }^{41}$.

Do obchodów Święta Żołnierza „całą Polonię oraz wszystkie Towarzystwa miejscowe, świeckie i kościelne" zachęcał montrealski Związek Weteranów Polskich. „Obchód nasz musi wykazać naszą wdzięczność serca Żołnierzom, którzy składaja w ofierze swoje życie na ołtarzu walki o wyzwolenie naszej Ojczyzny Polski. Żołnierz Polski niczego tak nie pragnie jak ciepła serc swoich Rodaków! Starajmy się więc, aby nie brakło żadnego Polaka w tym obchodzie w Montrealu! Wykażmy naszemu Żołnierzowi, że Naród ceni jego trudy i znoje!" Do udziału w uroczystości zaproszono także reprezentantów innych narodowości ${ }^{42}$. Zorganizowane 16 sierpnia obchody wypadły „imponująco". Mimo deszczowego dnia na placu zjawiło się ponad tysiąc osób: przedstawiciele Wojska Polskiego, byli żołnierze armii Czechosłowacji, inżynierowie i technicy, uchodźcy wojenni, w tym przybyli niedawno z Francji, miejscowi Czechosłowacy, a także żołnierze kanadyjscy. Orkiestra odegrała hymny: polski, czechosłowacki i kanadyjski. Na ustrojonej w barwy polskie i brytyjskie scenie wspominano polski czyn zbrojny podczas I wojny światowej. Nawiązując do Marszałka Józefa Piłsudskiego, odegrano utwór My, Pierwsza Brygada. Głos zabrali także polscy dyplomaci, konsul generalny Czechosłowacji

${ }^{39}$ IPMS, A.X.1/4, Załącznik „Imprezy” do Sprawozdania kulturalno-oświatowych i propagandowych Polskiej Misji Wojskowej w Kanadzie, [b.m., b.d.], k. nlb.

${ }^{40}$ Kronika, „Związkowiec”, 16 VIII 1942, nr 33; IPMS, A.X.1/4, Załącznik nr 3 „Wyjazdy propagandowe oficerów i szeregowych na terenie USA i Kanady” do referatu Dowództwa Oddziałów WP w Kanadzie „Akcja oświatowo-propagandowa na terenie USA i Kanady” za okres od 1 IX 1941 do 30 IV 1942, [b.m., b.d.], k. nlb.

${ }^{41}$ Z Obchodu Święta Żotnierza Polskiego, „Zwiąkowiec”, 30 VIII 1942, nr 35.

${ }^{42}$ Ibidem. 
i szef Czechosłowackiej Misji Wojskowej w Kanadzie, przedstawiciele stowarzyszenia uchodźców, Stowarzyszenia Inżynierów i Techników Polskich w Kanadzie, a także kanadyjskiej armii ${ }^{43}$. Z okazji Święta Wojska Polskiego 315 placówka Weteranów Polskich przy Legionie Kanadyjskim z Hamilton 22 sierpnia zorganizowała Social Party, na której oprócz zwykłych atrakcji piknikowych magnesem mieli być polscy lotnicy ${ }^{44}$.

Jak wiemy, nie udało się powtórzyć sukcesu z budowy na kanadyjskiej ziemi drugiej Błękitnej Armii. Jesienią 1942 r. szef Polskiej Misji Wojskowej płk Sznuk zauważył, że „koszta utrzymania Misji w stosunku do wyników rekrutacyjnych sa znaczne”, a usprawiedliwiać je miały właśnie osiagnięcia propagandowe ${ }^{45}$. Niespodziewanie już wkrótce żołnierzy PSZ spotkać można było w niemal każdej większej kanadyjskiej miejscowości, od okna na Atlantyk w Montrealu po Vancouver i Victorię na wybrzeżu Pacyfiku.

W symboliczny dzień, 11 XI 1946 r., do Kanady dotarła pierwsza grupa zdemobilizowanych polskich żołnierzy. Do legendarnego pirsu $\mathrm{nr} 25 \mathrm{w}$ Halifax, do którego wcześniej przybijały statki transportujace emigrantów z Europy i z którego na europejski teatr wojny odpływali kanadyjscy i polscy żołnierze, przybyła zorganizowana żołnierska wspólnota, która jeszcze 3 X 1946 r. we włoskiej miejscowości Falconara utworzyła Stowarzyszenie Polskich Kombatantów (SPK) w Kanadzie. Przyjazd byłych polskich żołnierzy stanowił wielkie wydarzenie dla Polonii kanadyjskiej. Powojenna fala byłych żołnierzy i jeńców wojennych liczyła początkowo blisko 5 tys. osób, które skierowano do ciężkiej dwuletniej pracy kontraktowej na farmach rozrzuconych po preriowych prowincjach. Do połowy lat pięćdziesiątych w Kanadzie, głównie w ośrodkach miejskich, znalazło się ponad 55 tys. Polaków niemogących powrócić do zajętego przez komunistów kraju. Wśród nich, obok kombatantów, były członkinie Pomocniczej Służby Kobiet, rodziny żołnierzy, jeńcy wojenni czy sieroty.

Wśród zdemobilizowanych żołnierzy znalazło się wiele wybitnych postaci. Jeszcze w czasie wojny w Kanadzie polskie oddziały tworzył gen. bryg. Stefan Sznuk, którego odnalazła administracja federalna. Po wojnie przybyli także gen. dyw. Tadeusz Kasprzycki, gen. dyw. Antoni Szylling, gen. dyw. Emil Krukowicz-Przedrzymirski, gen. dyw. Mieczysław Norwid-Neugebauer, gen. bryg. Wacław Stachiewicz, gen. bryg. Stanisław Ujejski, gen. bryg. Romuald Wolikowski, gen. bryg. Tadeusz Majewski, kmdr Eugeniusz Pławski czy w 1972 r. gen. bryg. Wilhelm Orlik-Rückemann. Kanadę odwiedzali gen. Michał Tokarzewski-Karasiewicz, gen. dyw. Bronisław Duch, gen. dyw. Stanisław Kopański, gen. dyw. Marian Kukiel, gen. dyw. Tadeusz Bór-Komorowski czy

\footnotetext{
${ }^{43}$ A. Kulas, Gtosy Czytelników, Z Obchodu Dnia Żotnierza w Montrealu, „Związkowiec”, 13 IX 1942, nr 37.

${ }^{44}$ Kronika, „Zwiąkowiec”, 23 VIII 1942, nr 34.

${ }^{45}$ IPMS, A.X.1/2, Sprawozdanie płk. Sznuka do wiceministra Spraw Wojskowych gen. I. Modelskiego z działalności propagandowej, Windsor, 13 XI 1942, k. nlb.
} 
gen. Władysław Anders, który otrzymał tytuł honorowego obywatela Winnipeg i Fort William, a jego dzieci i wnuki mieszkały w Montrealu ${ }^{46}$. Przede wszystkim symbolem nieugiętej postawy patriotycznej i miłości do ojczyzny pozostawał gen. Kazimierz Sosnkowski, który do Kanady przybył w 1944 r. Z uwagi na konsekwentny, niezłomny sprzeciw wobec geopolitycznego podporządkowania Polski Sowietom początkowo odmówiono mu wydania wiz wjazdowych do Wielkiej Brytanii i Stanów Zjednoczonych. Przez wiele lat położona pod Montrealem farma w Arundel pełniła funkcję Sulejówka, miejsca swego rodzaju internowania, a później zamierzonego odosobnienia. „Jakkolwiek rzadko udzielał się Polonii, to jednak autorytet Generała był bezapelacyjny. Nigdy nie zbaczał z drogi, która była polską droga. Głos jego działał na Polaków jak dzwon Zygmunta, który odzywa się w specjalnych okolicznościach i ciężkich chwilach dla Polaków" ${ }^{47}$ - wspominał Franciszek Kozłowski. Sosnkowski, honorowy członek SPK, uczestniczył w manifestacjach patriotycznych, głównie w Montrealu, ale odwiedził także zachód kraju. W 1954 r. próbował ponownie włączyć się w życie „polskiego Londynu”. Stan zdrowia jednak sprawił, iż w kolejnych latach rzadko opuszczał swoją farmę w Arundel, choć jego głos - w postaci listów czy apeli - był wciąż mocny i powszechnie szanowany. „Widziano w nim żywy symbol ciagłości walki o niepodległość i tendencji zjednoczeniowych narodu" 48 - wspominał Tadeusz Brzeziński.

Na patriotyczne postawy Polonii olbrzymi wpływ wciąż mieli dyplomaci, jak ułan krechowiecki Wiktor Podoski czy wspomniany wyżej uczestnik Bitwy Warszawskiej 1920 r. Tadeusz Brzeziński. Także wielu spośród dipisów odniosło sukcesy w nauce, kulturze czy polityce. Życie naukowe w Montrealu w ramach Polskiego Instytutu Naukowego zorganizowała zaś Wanda Stachiewicz, żona byłego szefa Sztabu Naczelnego Wodza. W 1956 r. Wiktor Turek, żołnierz Armii Andersa, założył w Toronto Polsko-Kanadyjski Instytut Badawczy, z siedziba przy Kole SPK nr 20. Z kolei wieloletnim redaktorem „Związkowca” był Benedykt Heydenkorn, również żołnierz 2 Korpusu, przyjmujący jednak

${ }^{46}$ AAN, 2376/86, Korespondencja i dokumentacja z Mszy żałobnej odprawionej w Montrealu w intencji gen. Tokarzewskiego-Karasiewicza, Montreal-Londyn, maj-czerwiec 1964, k. 6-27; IPMS, A.39/32, Pismo do J. Lipskiego w sprawie pobytu w Kanadzie gen. Karasiewicza-Tokarzewskiego, Londyn, 4 III 1952, k. nlb.; $Z$ pobytu Gen. W. Andersa w Kanadzie, „SPK w Kanadzie”, IV 1962, nr 1-2, s. 4.

47 F.T. Kozłowski, Ostatnia Droga Generała Sosnkowskiego, „Głos Polski”, 30 X 1969, nr 44, s. 9.

${ }^{48}$ AAN, 2729/166, Wspomnienie Tadeusza Brzezińskiego w pierwszą rocznicę zgonu gen. K. Sosnkowskiego. Zob. też: W. Babiński, Przyczynki historyczne do okresu 1939-1945, Londyn 1967, s. 556; Kazimierz Sosnkowski. Materiaty historyczne, oprac. J. Matecki, Londyn 1966, s. 217-240; Kazimierz Sosnkowski. Myśl - praca - walka. Przyczynki do monografii oraz uzupetnienia do materiałów historycznych Kazimierza Sosnkowskiego, oprac. S. Babiński, Londyn 1988, s. 258; M. Pestkowska, Kazimierz Sosnkowski, Wrocław 1995, s. 180-186; I. Wojewódzki, Kazimierz Sosnkowski podczas II wojny światowej. Ksiqże niezłomny czy Hamlet w mundurze?, Warszawa 2009, s. 421-423; L. Wyszczelski, Generat Kazimierz Sosnkowski, Warszawa 2010, s. 336-340. 
z czasem ugodową postawę wobec władzy komunistycznej nad Wisła, co spotykało się ze zdecydowana krytyką SPK ${ }^{49}$. Karierę akademicką podjęło co najmniej kilkunastu członków SPK, wpływając na świadomość miejscowych elit. Stanisław Bóbr-Tylingo, powstaniec warszawski i żołnierz Brygady Świętokrzyskiej NSZ, był profesorem na uniwersytecie w Halifax. Doceniając biografię i zasługi, gen. bryg. Romualdowi Wolikowskiemu nadano tytuł doktora honoris causa Uniwersytetu Alberty w Edmonton.

Żołnierskie więzi podczas rażąco ciężkiej pracy na farmach oraz w późniejszych latach utrzymywano dzięki SPK liczącemu ponad 20 rozsianych po całej Kanadzie oddziałów. Nie było to stowarzyszenie wspominkowo-samopomocowe o wojskowej hierarchii, lecz jedna z najżywotniejszych polonijnych organizacji o szerokim polu zainteresowań, a jej członkowie rozwinęli wszechstronna aktywność także w innych instytucjach, pełniąc tam istotne funkcje. SPK stawiało sobie za główny cel „utrzymanie i realizację wśród wychodźstwa polskiego i innych społeczeństw świata idei Niepodległej i Wolnej Polski”. Istotnymi zadaniami była „obrona i szerzenie prawdy o wkładzie i udziale polskim w drugiej wojnie światowej”, a także „stworzenie wśród Polaków w Kanadzie, a w szczególności wśród młodego pokolenia, twórczego i dynamicznego ruchu kulturalnego, opartego na tradycji narodowej i organicznych związkach z cywilizacją chrześcijańską" ${ }^{50}$ - czytamy w statucie stowarzyszenia. Szczególnie w pierwszych latach po wojnie w przestrzeni publicznej pojawiało się dużo, często inspirowanych przez władze komunistyczne, negatywnych opinii o kombatantach, a także o Polsce. Prostowanie fałszywych informacji było jednym z elementów działalności m.in. koła SPK w Edmonton ${ }^{51}$.

„W wielotysięcznej rzeszy Polaków w Kanadzie Stowarzyszenie Polskich Kombatantów ma bardzo ważne zadanie do spełnienia. Jest nim utrzymywanie poczucia jedności i wierności tym ideałom, które wiodły Polskę przez jej pierwsze Tysiąclecie" ${ }^{52}$ - pisał z kolei bp Władysław Rubin, uczestnik kampanii wrześniowej, ale przede wszystkim delegat prymasa Polski dla duszpasterstwa emigracji polskiej. Z uwagi na olbrzymie odległości niezwykle istotnym ogniwem spajającym wszystkie koła był kwartalnik „SPK w Kanadzie”, którego pierwszy numer ukazał się w 1962 r. Poszczególne koła wydawały również własne biuletyny. W Kanadzie w ścisłej współpracy z SPK działały także inne organizacje grupujące byłych żołnierzy walczących w ramach konkretnych formacji czy też rodzajów broni, jak koła Armii Krajowej, Stowarzyszenie

${ }^{49}$ Oświadczenie Rady Stow. Polskich Kombatantów w Kanadzie, „SPK w Kanadzie”, I 1967, nr 1 (21), s. 6. Zob. m.in.: A. Reczyńska, Polska emigracja do Kanady w drugiej połowie $X X w$. $i$ jej wptyw na przemiany polskiej grupy etnicznej $w$ tym kraju, w: Niuanse wyobcowania. Diaspora i tematyka polska w Kanadzie, red. A. Branach-Kallas, Toruń 2014, s. 25.

${ }^{50}$ Statut Stowarzyszenia Polskich Kombatantów w Kanadzie, Winnipeg 1948, s. 3-5.

${ }^{51}$ Czterdzieści lat $w$ stużbie idei Stowarzyszenia Polskich Kombatantów. SPK w Kanadzie, Inc. Koło nr 6-Edmonton, red. M. Carlton, Edmonton 1988, s. 78.

${ }^{52}$ List bp. W. Rubina do SPK $w$ Kanadzie, „SPK w Kanadzie”, V 1965, nr 3 (15), s. 1. 
Kawalerii i Artylerii Konnej, Związek Spadochroniarzy, Stowarzyszenie Żołnierzy 1. Dywizji Pancernej, Stowarzyszenie b. Żołnierzy 6-go Pancernego Pułku „Dzieci Lwowskich” czy też Stowarzyszenie Lotników Polskich. Część z nich, podobnie jak weterani z I wojny, utworzyła polskie oddziały w ramach Royal Canadian Legion, umacniając polsko-kanadyjskie braterstwo broni. Warto też wspomnieć o aktywności Stowarzyszenia Techników Polskich w Kanadzie, skupiającego ewakuowanych w czasie wojny specjalistów współpracujących z kombatantami. SPK w Kanadzie utrzymywało także bardzo bliskie kontakty z kolegami ze Stanów Zjednoczonych, o czym świadczy chociażby udział prezesa Stanisława Gierata w walnym zjeździe w 1962 r., a także Federacja Światową w Londynie, stanowiąc jeden $\mathrm{z}$ jej filarów ${ }^{53}$.

Przede wszystkim jednak przystępując już w 1949 r. do Kongresu Polonii Kanadyjskiej (KPK), organizacje kombatantów włączyły się w główny nurt polonijnego życia, nadając mu nowy impet. Analizując liczebność i wpływy kombatantów podczas walnego zjazdu KPK w 1958 r., możemy ocenić, iż stanowili oni jedna trzecią zasobu organizacji skupionych w Kongresie ${ }^{54}$. Koła SPK sumiennie opłacały składki członkowskie KPK, użyczały swojej infrastruktury czy zasilały organizacje sprawdzonymi osobami. Kombatanci szybko zdobyli wysoką pozycję wśród Polonii, a wielu byłych żołnierzy wkrótce zostało liderami polonijnych społeczności, stając m.in. na czele KPK. Kombatanci wzmocnili antykomunistyczny nurt wśród Polonii, wspierając rząd RP w Londynie oraz jego inicjatywy, takie jak Skarb Narodowy. „[...] Zwracamy się do Was, drodzy Kombatanci, z prośbą byście stali się tym pomostem między zrzeszeniami polskimi, który by zagoił rany, usuną nieporozumienia, który by zjednoczył wszystkich w olbrzymim wysiłku dla dzieła Millenium"55 - apelował prezes KPK Zygmunt Jaworski, zabiegajacc o zaangażowanie SPK w dzieło Funduszu Wieczystego Millenium.

Polskie mundury i sztandary, które stały się przedmiotem dumy i symbolem walki o wolną i niepodległą Polskę, podziwiać można było nie tylko podczas polonijnych uroczystości, ale także oficjalnych kanadyjskich świąt, jak Decoration Day (2 czerwca), Dominion Day (1 lipca), czy defilad z okazji obchodzonego 11 listopada Remembrance Day i Warriors' Day (sierpień).

${ }^{53}$ IX Walny Zjazd SPK w Kanadzie, „SPK w Kanadzie”, IV 1962, nr 1-2, s. 2.

${ }^{54}$ Stosunek głosów przynależnych delegatom „wojskowym” do „cywilnych” wynosił 46 do 101, przy czym kombatantów cechowały zdecydowana jedność ideowa i zbieżność poglądów, dodatkowo zwiększająca ich wpływy. VIII Walny Zjazd KPK odbył się w październiku 1958 r. w domu SPK w Toronto, a wśród 13 członków nowego zarządu KPK było 4 kombatantów, w tym prezes Zygmunt Jaworski. Po Sejmie Polonii kanadyjskiej, „Biuletyn Informacyjny Koła SPK nr 20 w Toronto", XII 1958, nr 3/58, s. 3.

${ }^{55}$ Zgrupujcie wszystkich koło Dzieła Millenium, „SPK w Kanadzie”, VII 1967, nr 3 (7), s. 12. Zob. też: D. Bieżanek, Fundusz Wieczysty Milenium, Toronto 2001; W. Gliński, Obchody Milenium Chrztu Polski wśród Polonii kanadyjskiej, w: Polonia kanadyjska. Przeszłość i teraźniejszość, red. W. Gliński, Warszawa 2016, s. 241-251. 
Wymowna demonstracje polsko-kanadyjskiego braterstwa broni stanowiły uroczystości w miejscach upamiętniających poległych nieznanych żołnierzy. Kombatanci odegrali niezwykle istotna rolę w budowaniu bliskich relacji ze społeczeństwem kanadyjskim, wychodzących daleko poza kręgi weteranów. Kombatanci do współpracy angażowali nie tylko Polonię, ale również władze kanadyjskie wszystkich szczebli, przedstawicieli wojska, duchowieństwa, media, co było szczególnie widoczne przy obchodach rocznic bitwy o Monte Casino, w której uczestniczyły także oddziały kanadyjskie ${ }^{56}$. Coraz mocniej zacieśniała się trwała i silna więź, jaką jest braterstwo broni i wypływająca z niej solidarność. „Znalazłszy się na terenie Kanady, potrafiliście nawiązać serdeczne i bliskie stosunki ze społeczeństwem kanadyjskim, co jest niezmiennie ważnym i pozytywnym czynnikiem i co zyskało Wam sympatię i uznanie ze strony oficjalnych przedstawicieli tego kraju"57 - oceniał gen. dyw. Tadeusz Bór-Komorowski. Potwierdzeniem tej opinii był list premiera Lestera Pearsona do uczestników zjazdu SPK. „W krótkim okresie dwóch dekad, od zakończenia II wojny światowej, kanadyjscy weterani polskiego pochodzenia w istotny sposób przyczynili się do rozwoju naszej kanadyjskiej wspólnoty i kultury"58 - czytamy w nim. Podobne opinie były powszechne także na poziomie rządów prowincji oraz władz lokalnych. Część wpływowych polityków, jak minister ds. weteranów Alfred Johnson Brooks, została honorowymi członkami SPK. W organizowane przez kombatantów uroczystości angażowali się przedstawiciele środowisk akademickich, sędziowskich, kulturalnych czy religijnych.

Przebieg świąt narodowych w Kanadzie po 1945 r. nie różnił się zbytnio od podobnych uroczystości $\mathrm{w}$ innych państwach anglosaskich. W tym kontekście szczególnie istotne były obchody świąt narodowych - 3 Maja (organizowane przeważnie przez KPK z dużym udziałem kombatantów), Święta Żołnierza i Święta Niepodległości (gdzie pierwszoplanowe role odgrywali kombatanci). Corocznie obchodzono także rocznice bitwy o Monte Cassino, wybuchu Powstania Warszawskiego, powstania styczniowego (szczególnie stulecie), mordu katyńskiego, 400-lecie unii lubelskiej czy też 300-lecie odsieczy wiedeńskiej, rocznice obrony Lwowa, milenium chrztu Polski czy też rocznice kopernikańskie i stulecie śmierci Adama Mickiewicza, której to uroczystości przewodniczył gen. Przedrzymirski. W 1966 r., roku milenium chrztu Polski, Święto Żołnierza obchodzono jako Święto Oręża Polskiego, nadając mu szerszą perspektywę, czcząc wszystkich, którzy w ciagu tysiąclecia polskiej państwowości stawali orężnie w obronie narodu i państwa. „W czasie tych

${ }^{56}$ Providence Watching. Journeys from Wartorn Poland to the Canadian Prairies, red. K. Patalas, Winnipeg 2003, s. 30, 139, 254.

${ }^{57}$ List gen. T. Bora Komorowskiego do uczestników XI Walnego Zjazdu SPK, „SPK w Kanadzie", V 1965, nr 3 (15), s. 4.

${ }^{58}$ List premiera L. Pearsona do uczestników XI Walnego Zjazdu SPK, „SPK w Kanadzie”, V 1965, nr 3 (15), s. 4. 
dziesięciu wieków Polska przechodziła nie tylko okresy potęgi i chwały, lecz również klęsk i upokorzeń, które jednak nigdy nie złamały ducha narodu. Z klęsk tych naród nasz dźwigał się zawsze silniejszy bo zjednoczony. Ufajmy, że i w przyszłości będzie tak samo" 59 - mówił podczas uroczystości w Toronto gen. Tadeusz Majewski. Odprawiano nabożeństwa w intencji Polaków poległych w I i II wojnie światowej, a także bieżących wydarzeń nad Wisłą. Kontynuowano również obchody rocznic związanych z Marszałkiem Piłsudskim, szczególnie 100. rocznicę urodzin. Na mniejszą skalę organizowano rocznice urodzin i śmierci gen. Sikorskiego. Z kolei w ramach przygotowań do obchodów stulecia Kanady SPK włączyło się w inicjatywę budowy w Toronto pomnika Stanisława Gzowskiego, podkreślajacc, iż tak jak oni był kombatantem zmuszonym do opuszczenia ojczyzny ${ }^{60}$. Szeroko obchodzono również 100. rocznicę urodzin Marszałka Piłsudskiego. Święto Marynarki odbywało się głównie w związanych z morzem ośrodkach, jak Vancouver. W mniejszym gronie obchodzono święta pułkowe. W Windsor doszło do oddzielnego zlotu kawalerii i artylerii, w Toronto świętowano 25-lecie Samodzielnej Brygady Strzelców Karpackich, a w Hamilton miał miejsce Zlot Lotników Polskich.

Liczba dat i wydarzeń, które starano się uczcić, sprawiła, iż próbowano łączyć ze sobą różne obchody i organizować wspólne uroczystości, często trwające kilka dni, poświęcone poszczególnym wydarzeniom. Przykładowo w 1964 r. przypadało kilka ważnych okragłych rocznic, co dało sposobność do zorganizowania uroczystości czynu zbrojnego z ostatnich 50 lat, poczynając od wymarszu z Oleandrów Pierwszej Kompanii Kadrowej. W Montrealu cykl „wielkich rocznic” tradycyjnie zamykała manifestacja „O sprawiedliwość dla Polski”, z udziałem kanadyjskich czynników politycznych i wojskowych ${ }^{61}$. Z kolei nad Pacyfikiem o historycznych wydarzeniach opowiadali ich bezpośredni uczestnicy - legionista Bolesław Liszkowski, żołnierz września i PSZ J. Kostrzewa oraz powstaniec warszawski Henryka Filipowicz, ps. Joanna. Honorowy patronat nad uroczystościami objęła elita Vancouver - przedstawiciele władz prowincjonalnych i lokalnych, wszystkich rodzajów wojska czy środowisk akademickiego i sędziowskiego ${ }^{62}$. Wkrótce istotnym punktem licznych uroczystości było wręczanie odznaczeń i awansów, doceniając w ten sposób zasługi z okresu wojny, jak i późniejszą działalność na rzecz Polonii i Rzeczypospolitej.

Podobnie wielkie uroczystości odbyły się chociażby w 1979 r., kiedy to obchodzono 40. rocznicę wybuchu II wojny światowej oraz 35. bitew o Monte Cassino, Falaise, Arnhem i Powstania Warszawskiego. Obchody zorganizowane przez SPK w Ottawie, w samym sercu stolicy Kanady, miały charakter

\footnotetext{
${ }_{59}$ Święto Oręża Polskiego w Toronto, „SPK w Kanadzie”, X 1966, nr 4 (20), s. 19.

${ }^{60}$ Apel Zarzqdu Gtównego SPK w Kanadzie, „SPK w Kanadzie”, I 1967, nr 1 (21), s. 2.

${ }^{61}$ Montreal zamyka cykl wielkich rocznic $z$ Koła $n r$ 7, „SPK w Kanadzie”, I 1965, nr 1(13), s. $18-19$.

${ }^{62}$ Vancouverskie echa obchodu czynu zbrojnego, „SPK w Kanadzie”, I 1965, nr 1 (13), s. 20.
} 
niemalże kanadyjskiego święta, a przestrzeń publiczną zdominowały polskie mundury i sztandary oraz dźwięki Mazurka Dąbrowskiego, odegranego przez pełną orkiestrę Gwardii Pieszej Gubernatora Generalnego. Edward Schreyer był najwyższym rangą uczestnikiem uroczystości, w której wzięli także udział parlamentarzyści, przedstawicieli rządu oraz wojska oraz Polonia w liczbie tysiąca osób. Specjalny list na tę okoliczność nadesłał Jan Paweł II. Kombatanci nie pozostawali również obojętni na wydarzenia $\mathrm{w}$ kontrolowanej przez komunistów Polsce, stąd liczne akcje pomocy, udział w demonstracjach i podejmowane rezolucje. Pamiętając o swoim losie sprzed ponad 35 lat, kombatanci angażowali się w akcje sponsorowania sprowadzania do Kanady „emigracji stanu wojennego”. Sztandarów kombatanckich nie zabrakło podczas nabożeństw za Ojczyznę i ofiary stanu wojennego. Kombatanci aktywnie brali udział w pielgrzymkach do Kanady Jana Pawła II, wizytach prymasa Józefa Glempa czy premierów rządu RP w Londynie. Koła SPK stanowiąc niezachwiany kompas moralny Polonii, angażowały się w liczne zbiórki na potrzeby Polonii w Kanadzie, ale także istotne dzieła nad Wisła. Tak było chociażby z budową na Katolickim Uniwersytecie Lubelskim Kolegium Jana Pawła II. Samo tylko koło SPK w Edmonton w 1986 r. na ten cel przeznaczyło 5 tys. dolarów.

„Jak gdyby ironia losu - prawie dla wszystkich narodów, dla których dzień zakończenia pierwszej wojny był dniem narodzin wolności - dzień zakończenia drugiej wojny światowej był grobem tej wolności” - czytamy w biuletynie wydawanym w odległym Vancouver, podkreślającym znaczenie obchodzenia Święta Niepodległości, które nad Wisła zastapione zostało przez 22 Lipca - rocznice „otrzymania władzy przez reżim z rąk mocodawców z Kremla”63. „O Dwudziestym roku w Polsce Ludowej nawet mówić nie można, by nie urazić możnego Protektora" - podkreślano z kolei w Święto Żołnierza, przypominając znaczenie powstrzymania nad Wisła bolszewickiej nawały. „I dlatego emigracja, która przecież w większości pozostała za granica po to, aby mogła mówić prawdę, ma za zadanie obchodzić uroczyście przede wszystkim te rocznice narodowe, których dziś naród polski obchodzić nie może” - stwierdzał Wacław Mokrzycki. „I musimy robić to tak długo, aż przyjdzie błogosławiona godzina, w której zlikwiduje się obecny zbrodniczy porządek, ustalony przez wschodnich tyranów" - mówił podczas uroczystości w $1972 \mathrm{r}^{64}$

Szczególne znaczenie miały rocznice zbrodni katyńskiej. Starano się, aby we wszystkich miejscowościach, w których osiedlili się polscy żołnierze, odbywały się msze w intencjach pomordowanych oficerów. Efekt szerszej

${ }^{63}$ 11-ty Listopad, „SPK. Placówka nad Pacyfikiem. Biuletyn Informacyjny Koła SPK nr 3 w Vancouver", X-XI 1963, nr 7/63, s. 2.

${ }^{64}$ Cud nad Wisła, ,SPK. Placówka nad Pacyfikiem. Biuletyn Informacyjny Koła SPK nr 3 w Vancouver", VII-VIII 1972, nr 4/72, s. 6. 
współpracy stanowiła budowa pomnika katyńskiego w Toronto, odsłoniętego w 40. rocznicę zbrodni. Była to prawdziwa manifestacja patriotyczna. Mszę św. sprawował kard. Władysław Rubin, a w uroczystościach udział wzięło ponad 200 pocztów sztandarowych oraz tysiące osób. Odsłonięcie pomnika przez wiele miesięcy znajdowało się w centrum przeżyć Polonii kanadyjskiej, a szczególnie kombatantów, którzy - tak jak w Edmonton - często byli głównymi organizatorami uroczystości. W obchodach zorganizowanych w Windsor przez SWAP udział wzięli dwaj więźniowie sowieckich obozów, liczna Polonia, a także minister spraw zagranicznych Mark MacGuigan czy władze miejskie ${ }^{65}$.

Organizacja obchodów rocznic i świąt państwowych była zapewne najbardziej widoczną na zewnątrz aktywnością kombatantów. Skupienie się na tej formie działalności - duża częstotliwość akademii i często szablonowy program - niekiedy niekorzystnie odbijało się na frekwencji. Nie zawsze spotykało się z entuzjazmem liderów Polonii. „Muszę wam wyznać z cała otwartością, że bynajmniej nie entuzjazmuję się wielką ilością jubileuszów i obchodów rocznicowych, w które tak obfituje nasze obecne życie zbiorowe" - przestrzegał z Arundel gen. Sosnkowski. W specjalnym liście skierowanym na uroczystości w stolicy Wielkiej Brytanii, ale przedrukowanym także w Kanadzie, zwracał uwagę na nadmiar świąt rocznicowych, wskazując, iż „są one tylko namiastką aktywności”, a nie celem pozostawania na obczyźnie. „Obchód rocznicowy staje się czymś jałowym i bezużytecznym, jeśli nie nawiązuje do spraw aktualnych i jeśli wspomnienia nie służą przyszłości” - przestrzegał. Zdaniem Sosnkowskiego czas, energia i środki materialne, przeznaczane na obchody rocznic, nie pozostawiają trwałego śladu wśród młodzieży, która w coraz bliższej perspektywie miała podjać po kombatantach trud obrony spraw polskich na Zachodzie ${ }^{66}$. Aktywność kombatantów wykraczała jednak znacznie szerzej niż organizacja akademii o wspominkowym charakterze.

SPK wspierało tendencje zjednoczeniowe wśród Polonii, a kombatanci zachęcani byli do angażowania się w prace innych cywilnych stowarzyszeń. SPK, jako członek KPK, działało także na rzecz integracji kombatantów z zakorzenioną już w Kanadzie Polonią, wzmacniało Kongres sprawdzona, patriotyczną siła, ale także pozwalało na koordynację przedsięwzięć, dawało poczucie jedności i wzmacniało potencjał całej Polonii, stanowiąc najliczniejszą organizację najmłodszej emigracji. Z pewnością było także grupą najbardziej zwartą i ideowo spójna, której przesłanie można streścić następująco: „zachowując pełną obywatelską lojalność w stosunku do Kanady, nigdy nie

\footnotetext{
${ }^{65}$ A. Rajski, op. cit., s. 73-74; S. Moćkun, Niechciana prawda. Kanada wobec ujawnienia zbrodni katyńskiej (1943-1945), „Dzieje Najnowsze” 2014, nr 1, s. 121; Czterdzieści lat w stużbie idei..., s. 233-235.

${ }^{66}$ K. Sosnkowski, Wspomnienia stużyć powinny przyszłości, „SPK w Kanadzie”, I 1965, nr 1 (13), s. 1.
} 
pogodzimy się z myśla, aby Polska, kraj naszych Ojców, z jej 1000-letnia wspaniała przeszłością historyczna miała pozostać krajem niewolnym, rzadzonym przez narzucone, a duchowo obce narodowi polskiemu, marionetki komunistyczne"67. Przy czym realizując własna agendę, o ile to możliwe unikali konfliktów i zabiegali o jedność Polonii. Dla przykładu w Montrealu powstała Federacja Polskich Stowarzyszeń Wojskowych w Prowincji Quebec. Z kolei w Toronto powołano Centralny Komitet Organizacji Weterańskich. Kombatanci i ich organizacje stanowiły przy tym środowisko najbardziej odporne na komunistyczną infiltrację, odcinając się ,jak najbardziej stanowczo i kategorycznie od wszystkich, którzy reprezentują narzucony Polsce reżym komunistyczny, lub wykonuja jego rozkazy"68. Ta klarowna i zasadnicza linia z pewnością miała wpływ także na postawy innych środowisk. Jej słuszność na łamach kwartalnika SPK potwierdzał m.in. przebywajacy w Kanadzie poeta i pisarz Bogdan Czaykowski ${ }^{69}$.

Gospodarność, przedsiębiorczość i pracowitość sprawiły, że organizacje kombatanckie stały się jednymi z najlepiej prosperujących finansowo polonijnych instytucji. „Świątynie duszy polskiej”, jak określano domy SPK, z salami na wynajem, popularnymi barami, w których organizowano dochodowe bingo, obok wpłacanych regularnie składek członkowskich, zapewniały niezależność finansowa. Swoimi składkami od 3 tys. ofiarnych członków (lata sześćdziesiąte) SPK w Kanadzie zasilało także ogólnopolonijne organizacje, w tym Kongres Polonii (wpłacając w 1966 r. ponad 2 tys. dolarów - dwa razy więcej niż Zwiazek Narodowy Polski i cztery razy więcej niż Związek Polaków w Kanadzie), Światowa Federację SPK, Instytut Polski im. J. Piłsudskiego czy Fundusz im. A. Mickiewicza. Przykładowo w samym tylko roku 1967 koło w Winnipeg na cele kulturalno-oświatowe bezpośrednio przeznaczyło ponad 3 tys. dolarów.

W domach SPK inwestowano w najnowocześniejszy sprzęt dostępny dla całej Polonii, podobnie jak zasób licznych bibliotek. Część oddziałów zorganizowała własne unie kredytowe i kasy pożyczkowe, często otwarte także dla osób spoza SPK. Z kolei urządzane bale, wieczorki taneczne, koncerty, pikniki czy spotkania sylwestrowe, obok istotnego charakteru integracyjnego, przynosiły dochód przeznaczany na konkretne cele. Duże znaczenie miały funkcjonujace przy niemal każdym oddziale Sekcje Pań. Prowadzono zbiórki na wsparcie inwalidów, opiekę nad cmentarzami wojennymi i grobami poległych kolegów. Wspierano budowę pomników (m.in. Kopernika w Montrealu), współfinansowano zespoły taneczne, kluby sportowe i orkiestry. Kombatanci

${ }^{67}$ Przed X. Walnym Zjazdem Delegatów SPK w Kanadzie, „SPK w Kanadzie”, IV 1963, nr 2 (6), s. 1.

${ }^{68}$ Uchwata Zjazdu SPK $w$ sprawie infiltracji komunistycznej, „SPK w Kanadzie”, X 1965, nr 4 (16), s. 5.

${ }^{69}$ B. Czaykowski, Odpowiedź na zaproszenie, „SPK w Kanadzie”, X 1965, nr 4 (16), s. 9. 
angażowali się także w ogólnokanadyjskie zbiórki, tak jak w przypadku Funduszu Wieczystego Millenium, stanowiąc trzon inicjatywy. Dzięki swojej społecznej i gospodarczej aktywności z każdym mijającym rokiem kombatanci coraz mocniej zakorzeniali się w nowym kraju i środowisku, szybko stając się mocnym filarem Polonii.

Polskie małżeństwa zawierane w latach pięćdziesiątych odmłodziły Polonię. Napływ Polaków - byłych żołnierzy dał także nowy impuls dla polonijnej opieki duszpasterskiej, powodujac powstanie nowych parafii i wspierając budowę kościołów. W świątyniach obok obrazów Matki Boskiej Częstochowskiej pojawiały się witraże Matki Boskiej Kozielskiej (Katyńskiej), Cudu nad Wisłą (parafia św. Trójcy w Montrealu) czy freski zniszczonej po Powstaniu Warszawskim stolicy (parafia św. Józefa w Branford). W Chatham w Ontario powołując w $1957 \mathrm{r}$. nowa polska parafię, weterani wojenni zaproponowali wezwanie Matki Boskiej Zwycięskiej z Kozielska, dla których obraz ten był symbolem wolności ${ }^{70}$. Okazję do manifestacji patriotyczno-religijnych stanowiły spotkania z gen. dyw. bpem Józefem Gawlina ${ }^{71}$. „Kolegom ze wspólnej drogi żołnierskiej ku Wolnej Polsce [...] życzę, by trwali wiernie i ufnie przy tych ideałach, które wiodły przez cierpienia i żołnierski trud" - dodawał z kolei otuchy bp Rubin, były żołnierz Armii Andersa ${ }^{72}$.

Pojawienie się w Kanadzie i Stanach Zjednoczonych polskich żołnierzy z pewnościa rozpaliło serca wielu Polaków. Bogata działalność kulturalna sprawiła także, iż w oczach Kanadyjczyków Polacy sa narodem nie tylko bardzo pracowitym, ale także posiadającym piękną historią i bogatą kulturę. Przy placówkach SPK czy SWAP powstawały biblioteki, tworzyły się chóry, teatry czy przeróżne grupy zainteresowań. W domach SPK urządzano wystawy, koncerty i odczyty, swoim zakresem daleko wykraczające poza tematykę historyczną. Kombatanci włączyli się także w redakcję prasy polonijnej, z czasem zakładając własne pisma. Lokale SPK w wielu miejscach stały się centrami życia polonijnego ${ }^{73}$. Koła SPK angażowały się w organizację wystaw sztuki ludowej, wernisaży czy koncertów. Byli żołnierze zdecydowanie cenili edukację i wykształcenie, których pozbawiła ich wojna. Statystyki pokazuja, iż 90\% ich dzieci ukończyło studia, niejednokrotnie odnosząc sukcesy zawodowe w społeczeństwie kanadyjskim ${ }^{74}$. Priorytetem wielu kół SPK była opieka nad młodzieżą która starano się utrzymać w kręgu kultury i języka polskiego. Stąd mocno wspierano „przyszłość i dorobek” kół kombatanckich,

${ }^{70}$ Leksykon geograficzno-historyczny parafii $i$ kościołów polskich $w$ Kanadzie, red. E. Walewander, t. I, Lublin 1992, s. 60, 83, 101.

${ }^{71}$ Ibidem, s. 143.

72 Wpis do Księgi Pamiatkowej, „SPK. Placówka nad Pacyfikiem. Biuletyn Informacyjny Koła SPK nr 3 w Vancouver", VII-VIII 1972, nr 4/72, s. 8.

${ }^{73}$ Zob. E. Soltys, B. Heydenkorn, Trwanie $w$ walce - kulturowa analiza SPK $w$ Kanadzie, Toronto 1992.

${ }^{74}$ Providence Watching..., s. 21-22. 
jaki stanowił ruch harcerski ${ }^{75}$. „Koło przestało być kawalerskim. Ma dzieci. Ma bardzo dużo dzieci i za wychowanie tych dzieci jest odpowiedzialne. $\mathrm{Ma}$ dzieci to znaczy, że ma po co żyć, bogacić się i pracować"76 - czytamy w sprawozdaniu z działalności koła SPK w Winnipeg, które w 1962 r. prowadziło zajęcia harcerskie dla 165 młodych osób. „Za kilka lat, gdy nas nie stanie, nasza młodzież będzie musiała przejać realizację naszych idei i prac"77 - czytamy w jednym z dokumentów X Walnego Zjazdu. „Jako żołnierze walczyliśmy o wolność naszej ojczyzny, jako kombatanci walczymy o to nadal, choć w innej formie. Nadszedł teraz czas, że jeszcze jedną walkę, walkę o duszę polskiego dziecka musimy wygrać"78 - mówili kombatanci, organizując koła młodzieży, do których wstęp otwarty był dla całej polonijnej młodzieży, także tej spoza kombatanckich rodzin. SPK wspierało organizowane w Barry's Bay zloty młodzieży z całej Kanady czy światowe spotkania harcerskie, zwracając koszty podróży młodzieży $\mathrm{z}$ odległych prowincji ${ }^{79}$. Kombatanci sumiennie zaangażowali się we wsparcie polskiego szkolnictwa, fundując stypendia dla studentów czy użyczając polskim szkołom i innym organizacjom pomieszczeń swoich domów, a nawet prowadząc własne szkoły.

Przez kolejne dziesięciolecia na emigracji nie malały zapał i chęć działalności, dając przykład nowemu pokoleniu Polonii. Domy kombatanta stały się miejscem spotkań międzypokoleniowych, przystanią polskości, promieniując na otoczenie i odgrywając istotną rolę w ożywieniu tzw. starej Polonii. Byli żołnierze wnieśli inicjatywę, dynamizm i świeżość, także języka i kultury. Teatry, zespoły ludowe czy chóry, o ile nie były prowadzone przez SPK, to z pewnością z kombatantami w składzie. Kombatanci zdobyli także uznanie całej społeczności kanadyjskiej oraz zaufanie władz każdego szczebla. Wskazówki, jak w nowym kraju postępować „właściwa drogą i we właściwym kierunku”, zapewniając „wartościowy posag moralny" ${ }^{80}$, pozwoliły zachować zdecydowane oblicze ideowe nie tylko SPK, ale znacznej części Polonii. „Ale przede wszystkim SPK miało zawsze i ma to co się nazywa charakterem: odwagę przekonań i odwagę ich głoszenia w czasach sprzyjających raczej tchórzliwemu kombinatorstwu" - czytamy w ukazujących się w Montrealu „Wiadomościach Polskich”"

${ }^{75}$ Czterdzieści lat w stużbie idei..., s. 208-210, 423-429.

${ }^{76}$ Nasz dorobek, „SPK w Kanadzie”, IV 1962, nr 1-2, s. 14.

77 Walny Zjazd w trosce o mtode pokolenie, „SPK w Kanadzie”, VII 1963, nr 3 (7), s. 13.

${ }^{78}$ Koto mtodzieży w Port Arthur, „SPK w Kanadzie”, VII 1963, nr 3 (7), s. 13.

${ }^{79}$ Ibidem, 15.

${ }^{80}$ Punkt zwrotny, „Odtrabiono. Biuletyn Informacyjno-Dyskusyjny SPK w Kanadzie, Koło nr 2 w London", I-II 1960, nr 1, s. 4.

${ }^{81}$ Cyt. za: Pozjazdowe echa, „SPK w Kanadzie”, VII 1963, nr 3 (7), s. 16. 


\section{Streszczenie}

Mundur polskiego żołnierza, obok kościoła, szkoły czy chóru, stał się jednym z głównych nośników polskości wśród Polonii kanadyjskiej. Wpisał się na stałe w historię wielu polonijnych rodzin, pozostając powodem do dumy z polskich korzeni. Powstańcy listopadowi, żołnierze Błękitnej Armii, ochotnicy do PSZ czy po wojnie tysiące zdemobilizowanych żołnierzy stanowili fundament patriotycznej Polonii, równolegle zabiegając o wysoka pozycję w społeczeństwie kanadyjskim. Na przykład Walter Natynczyk, syn żołnierza 2 Korpusu Aleksandra Natynczyka, zafascynowany opowieściami ojca czołgisty został najwyższym ranga kanadyjskim wojskowym. Mundur stanowił jeden z najważniejszych czynników zachowania polskości, bez której nie utrzymałaby się ona w kanadyjskiej mozaice narodowościowej.

\section{The Importance of the Polish Soldier's Uniform in Cultivating Tradition and Patriotism among Canadian Poles}

The uniform of a Polish soldier, next to the Polish Church, school or choir, became one of the main carriers of Polishness within the Canadian Polish community. It became a permanent part of the history of many Polish diaspora families, remaining a source of pride in Polish roots. The November insurgents, Blue Army soldiers, volunteers of the Polish Armed Forces or thousands of soldiers demobilised after the war formed the foundation of patriotic Polonia, while striving for a high position in the Canadian society. For example, Walter Natynczyk, the son of a soldier of the Second Corps Aleksander Natynczyk, fascinated by the stories of his father tank crewman, became a Canadian military officer of the highest rank. The uniform was one of the most important factors in maintaining Polishness without which it would not have survived in the Canadian national mosaic.

\section{Bibliografia}

Bieżanek D., Fundusz Wieczysty Milenium, Toronto 2001.

Czterdzieści lat w stużbie idei Stowarzyszenia Polskich Kombatantów. SPK w Kanadzie, Inc. Koto $n r$ 6-Edmonton, red. M. Carlton, Edmonton 1988.

Gliński W., Obchody Milenium Chrztu Polski wśród Polonii kanadyjskiej, w: Polonia kanadyjska: przeszłość i teraźniejszość, red. W. Gliński, Warszawa 2016.

Kmietowicz F., Polskie Sity Zbrojne w Kanadzie podczas drugiej wojny światowej, Windsor 1984.

Kos-Rabcewicz-Zubkowski L.J., Alexandre-Edouard Kierzkowski, Patriote Polonais, réfugié au Canada (1816-1870), „Le Bulletin des Recherches Historiques” 1954, t. LX, nr 4.

Leksykon geograficzno-historyczny parafii i kościołów polskich w Kanadzie, Lublin 1992.

Makowski B., Polska emigracja w Kanadzie, Linz-Salzburg 1951.

Makowski W., The Polish People in Canada. A Visual History, Montreal 1987.

Małecki Z., Księga jubileuszowa 65-lecia Zwiazku Weteranów Polskich im. Marsz. Józefa Pitsudskiego w Montrealu, 1930-1995, Montreal 1995.

Moćkun S., Bezpieczna przystań. Kanada i Polonia kanadyjska wobec Polski i Polaków w latach 1939-1945, Warszawa 2015.

Moćkun S., Kultywowanie tradycji polskich $w$ Kanadzie przez Polonię $i$ emigrację wojenna w latach 1939-1945, w: Pary $\dot{z}$ - Londyn - Monachium - Nowy Jork. Powrześniowa emigracja niepodległościowa na mapie kultury nie tylko polskiej, t. II, red. V. Wejs-Milewska, E. Rogalewska, Białystok 2016.

Moćkun S., Niechciana prawda. Kanada wobec ujawnienia zbrodni katyńskiej (1943-1945), „Dzieje Najnowsze” 2014, nr 1. 
Plewko J., Duszpasterstwo Polonii w procesie jej integracji ze społeczeństwem kanadyjskim (1875-1988), Lublin 1995.

Rajski A., 100 lat Polonii w Windsor 1908-2008, Windsor 2008.

Reczyńska A., Polska diaspora w Kanadzie, w: Polska diaspora, red. A. Walaszek, Kraków 2001.

Reczyńska A., Polska emigracja do Kanady w drugiej połowie XX w. i jej wptyw na przemiany polskiej grupy etnicznej $w$ tym kraju, w: Niuanse wyobcowania. Diaspora i tematyka polska w Kanadzie, red. A. Branach-Kallas, Torun 2014.

Smoliński J., Polonia obu Ameryk w wojskowo-mobilizacyjnych planach Rzadu RP na uchodźstwie (1939-1945), Warszawa 1998.

Soltys E., Heydenkorn B., Trwanie w walce - kulturowa analiza SPK $w$ Kanadzie, Toronto 1992.

Turek W., Sir Casimir S. Gzowski, Toronto 1957.

Biog r a m: Slawomir Moćkun - dr; absolwent Uniwersytetu Warmińsko-Mazurskiego w Olsztynie; pracownik Parlamentu Europejskiego w Brukseli. Jest autorem monografii pt. Bezpieczna przystań. Kanada i Polonia kanadyjska wobec Polski i Polaków w latach 1939-1945 (Warszawa 2015). E-m ail: smockun@gmail.com. 